ANNA GRĄDZKA

ALFRED F. MAJEWICZ

Katedra Orientalistyki Uniwersytetu Mikołaja Kopernika w Toruniu

International Institute of Ethnolinguistic and Oriental Studies (Stęszew)

\title{
JAPONICA W ARCHIWALIACH PO BRONISŁAWIE PIŁSUDSKIM \\ W BIBLIOTECE PAU I PAN W KRAKOWIE (8) \\ KORESPONDENCJA \\ PANI KIMIKO TORII DO BRONISŁAWA \\ ORAZ LIST PANA MITSUGO YOKOYAMY \\ Z POKŁADU S/S DAKOTA
}

Słowa kluczowe: Piłsudski Bronisław, Torii Ryzo, Torii Kimiko, Kawahara Misako, archiwalia po B. Piłsudskim w Krakowie, japońska emigracja do Ameryki, Japonia i Mongolia, S/S Dakota

Niniejszy materiał to kontynuacja prezentacji japoniców po Bronisławie Piłsudskim przechowywanych w Bibliotece Naukowej PAU i PAN w Krakowie rozpoczętej w tomie 43. tego „Rocznika” (zob. Grodziska 1998, Majewicz 1999, 2007, 2007a, 2008, 2009, 2012, 2015, 2016). W przeciwieństwie do poprzednich części cyklu, przedstawiane niżej dokonanie firmuje dwoje autorów: wstępne opracowanie prezentowanej tu korespondencji z archiwaliów japońskich pozostałych po etnografie zgodziła się przygotować studentka, dziś już absolwentka Zakładu Japonistyki Uniwersytetu Mikołaja Kopernika w Toruniu, pani Anna Grądzka. Wynik okazał się więcej niż zadowalający, stąd i wykazane współautorstwo. Wynik ten przypomina, że wielkie - i ostatecznie płonne - nadzieje były pokładane w powstałej w Uniwersytecie Jagiellońskim w 1987 roku japonistyce, której wielokrotnie i bezowocnie sugerowano zajęcie się tymi archiwaliami w ramach seminariów dyplomowych, gwarantując publikacje i perspektywy: był to dla Polski czas, kiedy naukowy świat czekał na pierwsze tomy już zainicjowanych prac nad edycją dzieł zebranych polskiego badacza, na rozpoznanie i rekonstrukcję treści nagrań dźwiękowych folkloru ajnuskiego wykonanych przez Piłsudskiego na początku XX wieku na Sachalinie i Hokkaido, na fachową kwerendę w archiwaliach po nim pozostawionych, o których wiedziano. Instytut Dziedzictwa Bronisława Piłsudskiego z własnym czasopismem i licznymi, oddzielnie ogłaszanymi monografiami miał dopiero powstać, pomniki uczonemu dopiero miano postawić. Japonistyka, na której pomoc liczono, postawiła na inne tematy dyplomowe, jakby nie 
wierząc w artykułowane potrzeby nauki oraz że „coś takiego” może być przedmiotem zainteresowań seminarzystów dyplomantów - cóż: po pierwsze okazało się, że można, po drugie - każdy ma swoje preferencje i perspektywy.

W niniejszej, ósmej już (a faktycznie dziesiątej) części cyklu uwagę czytelnika skupiamy na liście żony wybitnego etnologa, antropologa i archeologa japońskiego Ryūzō Torii, Kimiko, do Bronisława Piłsudskiego (rkps 4648, k. 31) oraz na liście niejakiego Jitsugo Yokoyamy, który dotyczy Piłsudskiego i znalazł się w jego archiwach (rkps 4648, k. 5), choć adresat nie został nazwany, napisanym na pokładzie statku płynącego z Japonii do Stanów Zjednoczonych - prawdopodobnie został on powierzony kapitanowi do przekazania wedle wskazówek.

\section{LIST KIMIKO TORII DO BRONISŁAWA PIŁSUDSKIEGO}

\section{Kontekst sytuacyjny}

Autorką listu była Kimiko Torii 鳥居きみ子 (1881-1959), małżonka wybitnego japońskiego etnografa, Ryūzō Torii 鳥居龍蔵 (1870-1953). Małżeństwo Torii było zaprzyjaźnione z Piłsudskim, który zapoznał się z Ryūzō tuż po swoim przybyciu do Tokio. Ryūzō, wówczas wykładowca na Wydziale Nauk Ścisłych Uniwersytetu Imperialnego w Tokio (東京帝国大学 Tōkyō Teikoku Daigaku, dzisiaj Uniwersytet Tokijski 東京大学 Tōkyō Daigaku), od młodości interesował się archeologią i antropologią, nic więc dziwnego że znaleźli wspólny język. Jak podano w artykule z 8 lutego, opublikowanym w „Tōkyō Asahi Shinbun” (東京朝日新聞), Torii zabrał Piłsudskiego (nazwanego tam ,rosyjskim antropologiem”) na stanowisko archeologiczne „pagórek muszlowy” (kaizuka 貝塚) do Nishigahara 西ヶ原 w tokijskiej dzielnicy Kita-Toshima 北豊島, i tam pokazał mu podnoszone z ziemi kawałki starej ceramiki i kamienne narzędzia. Sam Piłsudski w swoim liście z 30 lipca do Benedykta Dybowskiego pisał o Toriim tak: „Zapoznałem się z japońskim etnologiem tutaj. Pojechał on na Wyspy Kurylskie, i napisał książkę o tamtejszych Ajnach ${ }^{1}$. Jego miano to Pan Torii. Nie wiedział o twoim słowniczku². Powiedziałem mu o słowniczku, i próbowałem go zamówić

\footnotetext{
1 Wspominaną książką jest wydana w Tokio (Yoshikawa Kobunkan) w 1902 roku Chishima Ainu 千島アイヌ [Ajnowie z Wysp Kurylskich], przytoczono w niej duże fragmenty leksyki języka Ajnów kurylskich. Znacznie poszerzona wersja materiału wyszła w języku francuskim w 1918 roku jako Les Aïnou des Iles Kouriles w ramach „Journal of the College of Science”, Tokyo Imperial University, vol. XLII, Article 1. Etudes Archéologiques et Ethnologiques z zapisami leksyki języka Ajnów Kurylskich na s. 49-76.

2 Chodzi tutaj o Stownik narzecza Ainów, zamieszkujących wyspe Szumszu w łańcuchu Kurylskim przy Kamczatce ze zbiorów Prof. B. Dybowskiego, opublikowany w 1891 roku pod redakcją Ignacego Radlińskiego nakładem Akademii Umiejętności w Krakowie. Dybowski łącznie skompilował siedem słowników, z czego Radliński ogłosił drukiem pięć (ajnuski, trzy itelmeńskie
} 
z Galicji. Aktualnie, [Torii] jest w Mongolii” (Inoue \& Sawada 2010: 73). Można przypuszczać, że z okazji któregoś z późniejszych spotkań Piłsudski poznał również Kimiko i zaprzyjaźnił się z nią (Inoue \& Sawada 2010: 73).

Kimiko Torii, z domu Kimi Ichihara (w koseki (戸籍), japońskim rejestrze rodzin, figuruje zapis imienia Kimi キミ), poślubiła Ryūzō w 1901 roku. Znakomicie wykształcona i bardzo inteligentna (o czym świadczy sposób zapisu listu do Piłsudskiego), zapracowała samodzielnie na sławę w gronie etnografów. Została zaproszona przez rodzinę książęcą w rejon (mongolska jednostka administracyjna to „chorągiew”) Harqinu (Kharachin, dziś Mongolia Wewnętrzna w ChRL) do pracy w charakterze nauczycielki w Książęcej Szkole dla Dziewcząt. Wydatnie pomogła przybyłemu później mężowi w badaniach nad Mongołami i Mandżurami dzięki znajomości ich języków (Inoue \& Sawada 2010: 73-74). Jedną z ich wspólnych publikacji na temat Mongolii była Manmō-o futatabi saguru 満蒙を再び探る [Ponownie na badaniach w Mandżurii i Mongolii] z 1932 roku.

W tym miejscu warto wspomnieć, chociażby krótko, o osobie, którą Kimiko miała zastąpić na stanowisku nauczycielki. Była nią Misako Kawahara (河原操子, 1875-1945), która pracowała w różnych miejscowościach w Chinach i w Mongolii od 1902 do 1906 roku. Uważana za pionierkę w swojej wybranej profesji w Japonii mężczyźni dominowali w zawodzie nauczyciela i dopiero od 1916 roku zaczął się poważny wzrost liczby kobiet pracujących w szkołach - Kawahara została wytypowana przez sławną z pan-azjatyckich poglądów i postępowych prac na rzecz edukacji kobiet Utako Shimodę (下田歌子, 1854-1936) i w 1902 roku rozpoczęła karierę nauczycielską w Żeńskim Koledżu Wupeng w Szanghaju (gdzie uczyła jako jedyna kobieta). Polecona mongolskiemu księciu Gungsangnorbü przez polityka Yasugorō Sasakiego (佐々木安五郎), od grudnia 1903 roku objęła posadę nauczycielki dzieci księcia w Harqinie. W trakcie wojny Japonii z Rosją Kawahara pełniła również rolę szpiega, idealnie usytuowanego, by przekazywać japońskim siłom zbrojnym meldunki o posunięciach rosyjskich wojsk. Do Japonii powróciła w styczniu 1906 roku w towarzystwie trzech córek jednego z wysoko postawionych wasali księcia Mongolii, które przekazała pod nauczycielską opiekę swojej mentorce, Shimodzie. Kawahara opublikowała kilkanaście artykułów na temat pobytu w Mongolii oraz wspomnienia stamtąd w czasopiśmie „Fujo Shimbun” 婦女新聞, periodyku poświęconym edukacji kobiet, a także książkę zatytułowaną Mōko miyage 蒙古土産 [Pamiątka z Mongolii], w której romantyczne opisy stepowego kraju przeplatają się z precyzyjnymi opisami jego geografii oraz organizacji administracyjnej. Jej wkład w zacieśnienie i umocnienie relacji japońsko-mongolskich poprzez kultywowanie idei edukacji kobiet bez

i wschodnio-koriacki), dwa (aleuckie) pozostają niepublikowane i nieodnalezione (pewną część lokalnej leksyki aleuckiej Dybowski zawarł jednak w monografii Wyspy Komandorskie (Lwów 1885)). Słownik Dybowskiego-Radlińskiego zawiera najbogatszy zapis leksyki ajnuskiego języka Wysp Kurylskich, a ponadto jest to zapis języka z najbardziej na północ położonych wysp tego archipelagu. 
wątpienia odegrał bardzo ważną rolę w historii stosunków między tymi dwoma państwami (Boyd 2005, także Bao 2013, Bao \& Bao 2015).

Sytuacja, do której nawiązuje analizowany dokument, wydarzyła się 9 lutego 1906 roku. Małżeństwo Torii czekało na wizytę Piłsudskiego, lecz gdy minęła umówiona godzina, stwierdzili, że zapewne szalejące śnieżyce zatrzymały pociągi i ich gość nie przyjedzie. Wkrótce po tym, jak zmęczony Ryūzō usnął, Piłsudski jednak się pojawił - z oczywistych powodów spotkanie nie było udane. Następnego dnia, Kimiko wysłała do badacza list z przeprosinami (tzw. お詫びの手紙 owabi-no tegami) - ten, który przedstawiamy poniżej.

Oryginał listu

\section{Tohyo, 10 Terrier 1906.}

Bon cher nonsieur.

Tahuban wa mahoto ni go burei wo itashi machsta, hino wa gogo 3 jugors oik to zonji mashste, tanochinte matte armashita sjichgi maie, mach möhite, oile ga arimasen Deshita hara, omor mashita. hoose wa kyön yo ma oyuhe 20 . bensha ya toranai ns he to zonjite honciens mi Ha mó vive necata mai to ahirame mashita. soshite hom mavi ni wa. snherke fatigué de

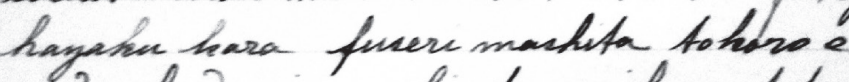
ouk henimeai mashi $k$, osihara tote

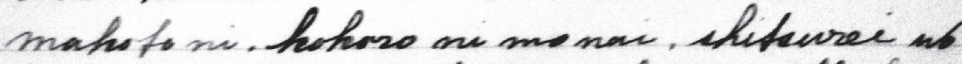

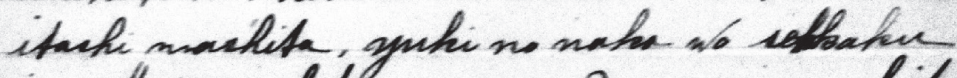

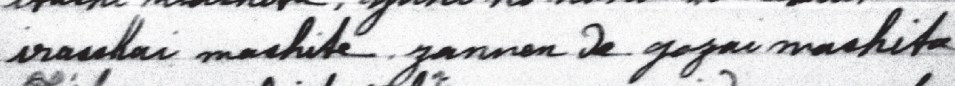
Fil some plait othimasarer maide oík hinuevi mashi. K. Joric 
Transkrypt odczytu

Tokyō, 10 Février 1906.

Mon cher Monsieur.

Sakuban wa makoto ni go burei wo itashi mashita, kinō wa gogo 3jigoro oide to zonji mashite, tanoshinde matte orimashita.

5 jisugi made, omachi mōshite, oide ga arimasen deshita kara, omoi mashita. kore wa kyō no yō na ōyuki de, densha ga tōranai no ka to zonjite, Monsieur ni wa mō oide nasara nai to akirame mashita. soshite Mon mari ni wa, sukoshi fatigué de hayaku kara fuseri mashita tokoro e oide kudasai mashi te, orikara tote, makoto ni, kokoro ni mo nai, shitsurei wo itashi mashiata. yuki no naka wo sekkaku irasshai mashite, zannen de gozai mashita. S'il vous plait ōkorinasara naide. mata oide kudasai mashi.

K. Torii

Rekonstrukcja tekstu i potencjalnego zapisu w grafice japońskiej

Tōkyō, 10 Février 1906.

Mon cher Monsieur.

Sakuban-wa makoto-ni go-burei-wo itashimashita, kinō-wa gogo 3ji-goro oide -to zonjimashite, tanoshinde matte orimashita.

5ji-sugi made, omachi mōshite, oide-ga arimasendeshita-kara, omoimashita. Kore-wa kyō-no yō-na ōyuki-de, densha-ga tōranai-no-ka-to zonjite, Monsieur-ni wa mō oide nasaranai-to akiramemashita. Soshite Mon mari-ni-wa, sukoshi fatigue-de hayaku-kara fuserimashita tokoro-e oide kudasaimashite, orikara tote, makoto-ni, kokoro-ni-mo nai, shitsurei-wo itashimashiata. Yuki-no naka-wo sekkaku irasshaimashite, zannen de gozaimashita. 
S’il vous plaît, ōkorinasaranaide. Mata

oide kudasaimashi.

K. Torii

東京, 10 Février 1906.

Mon Cher Monsieur.

昨晚は誠にご無礼を

いたしました、昨日は午後 3 時頃おいで

と存じまして、楽しんで待っておりました。

5 時過ぎまで、お待ち申して、おいでが

ありませんでしたから、思いました。

これは今日のような大雪で、電車が

通らないのかと存じて、Monsieurに

はもうおいでなさらないと諦めました。

そして Mon mariには、すこし fatigué で

早くから臥せりましたところへ

おいでくださいまして、折からとて、

誠に、心にもない、失礼を

いたしました。雪の中をせっかく

いらっしゃいまして、残念でございました。

S’il vous plaît お怒りなさらないで。また

おいでくださいまし。

鳥居きみ子

Przekład

Tokio, 10 lutego $1906 \mathrm{r}$.

Drogi Szanowny Panie,

jest nam niezmiernie przykro za uchybienie z wczorajszego wieczora. Kiedy nastała godzina trzecia po południu, z radością oczekiwaliśmy przybycia Waszmości. Gdy tak czekaliśmy, a minęła już piąta, pomyśleliśmy, że Waszmość już nie przybędzie. Uznaliśmy, że może to przez podobną do dzisiejszej śnieżycę pociąg nie dojechał i Waszmość już do nas nie zawita, więc się poddaliśmy [i przestaliśmy czekać]. Małżonek mój, jako że trochę był zmęczony, wkrótce usnął, a Waszmość zaraz po tym raczył przybyć. Była to ze strony męża prawdziwie niezamierzona nieuprzejmość. Jest nam z tego powodu niezmiernie przykro, gdyż Waszmość raczył się trudzić w taki śnieg. Uprzejmie prosimy, niech się Waszmość nie gniewa. Serdecznie zapraszamy do ponownych odwiedzin. Kimiko Torii ${ }^{3}$.

3 Odczytu, jak i rekonstrukcji tekstu i potencjalnego zapisu w grafice japońskiej, a także przekładu, pierwotnie dokonała Grądzka (2017: 32-38), stamtąd też pochodzi znaczna część sformułowań „kontekstu sytuacyjnego” w tej części artykułu. 
Kontekst sytuacyjny (c.d.)

Jak można wywnioskować z późniejszych zapisków pani Torii, Piłsudski nie pogniewał się na nich za zaistniałą sytuację (byłoby to sprzeczne z jego naturą), o czym może świadczyć chociażby fakt, że znajdował się w gronie osób żegnających ją na dworcu Shimbashi (新橋駅) w Tokio przed jej wyjazdem do Mongolii w marcu 1906 roku. Podarował jej fotografię oraz, co ją bardzo ujęło, pozdrowił po japońsku (Inoue \& Sawada 2010: 73-74). List jest napisany po japońsku z wtrąceniami z francuskiego - bardzo interesujące jest jednak to, iż całość zapisana jest $\mathrm{w}$ alfabecie łacińskim, $\mathrm{z}$ użyciem pięknego $\mathrm{i} \mathrm{w}$ miarę czytelnego stylu kaligraficznego Copperplate (bardzo popularnego zwłaszcza na Zachodzie w dokumentach pisanych piórem atramentowym). To bardzo jasno pokazuje, jaką erudycją dysponowała Kimiko. Można przypuszczać, iż ułożyła tekst w taki a nie inny sposób, by ułatwić Piłsudskiemu jego odczytanie i zrozumienie. Nie wiadomo, czy państwo Torii otrzymali odpowiedź na list, ale ewidentnie ten epizod nie pozostawił żadnych urazów. Bezpośrednia znajomość małżeństwa Torii z Bronisławem, choć zapamiętana przez obie strony i odnotowana w annałach nauki jako istotna, trwała krótko: Ryūzō jeszcze w marcu 1906 dotarł do Mongolii, a wspomniane dworcowe pożegnanie z Kimiko miało miejsce 5 marca tegoż roku.

Ryūzō Torii przełożył pracę Bronisława Piłsudskiego z 1909 roku Die Urbewohner von Sachalin (cf. CWBP 1, 222-235, 703-705) i opublikował jako Karafutotō-ni okeru senjūmin (樺太島に於ける先住民) w roku $1911 \mathrm{w}$ trzech czasopismach naukowych jednocześnie, prawdopodobnie też polecił publikację pierwszej w ogóle pracy Piłsudskiego o Ajnach w japońskim czasopiśmie „Sekai” 世界 w 1906 roku (cf. CWBP 1, 55-58; Sawada 2007: 55-56, 99-100, 150-151; Sawada \& Inoue 2010: 2: 68, 73, 74, 268, 389, 409, 430, 433).

Do pani Kimiko Torii postaramy się wrócić, gdyż w Bibliotece Naukowej PAU i PAN w Krakowie znajduje się jeszcze jeden jej list do Bronisława.

\section{LIST JITSUGO YOKOYAMY Z POKŁADU S/S DAKOTA}

\section{Kontekst sytuacyjny}

3 sierpnia 1906 roku, wypływając na pokładzie statku Dakota z portu w Jokohamie kursem do Seattle w USA, Bronisław Piłsudski na zawsze opuścił Japonię ale nie opuścił Japończyków! Okazja pokazania swojego afektu dla narodu, który dał mu nieformalny azyl po ucieczce z ciemiężącej go Rosji nadarzyła się wyjątkowo szybko, jak zaświadcza odnaleziony wśród archiwaliów po Bronisławie w krakowskiej Bibliotece PAU i PAN niezwykły dokument. 


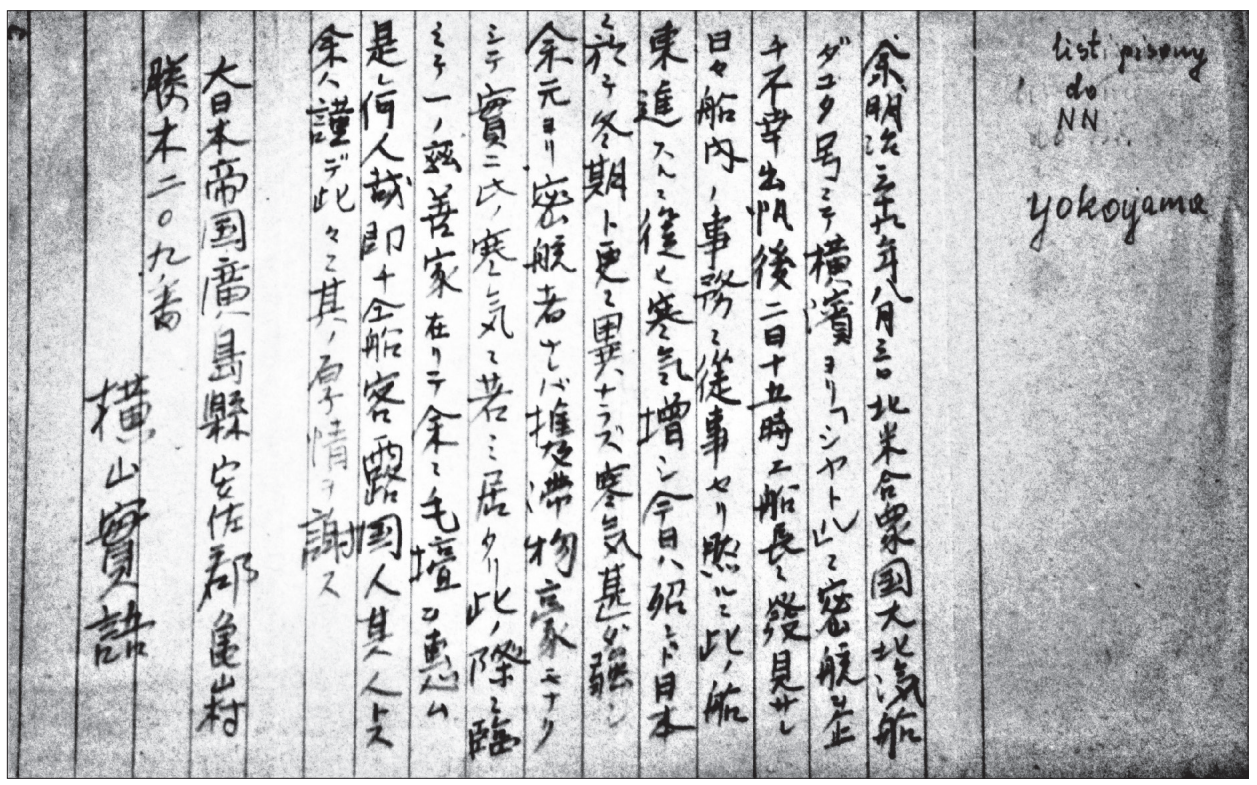

Transkrypt odczytu

余明治三十九年八月三日北米合衆国大北汽船

ダコタ号ニテ横濱ヨリ「シヤトル」二密航习企

于不幸出帆後二日十五時二船長二發見サレ

日々船内ノ事務二従事セリ然ル二此ノ船

東進スルニ従ヒ寒気増シ今日八殆ンド日本

二於テ冬期卜更々異ナラズ寒気甚ダ強シ

余元ヨリ密航者ナレバ携滞物豪モナク

シテ實二 $\mathbf{0}^{4}$ ノ寒気二苦ミ居タリ此ノ際二臨

ミテ一ノ慈善家在リテ余二毛擅 5 ヨ恵ム

4 Znak pisarski nieczytelny.

5 Odczyt drugiego znaku złożenia o niewątpliwym znaczeniu 'pled, koc, dera' w rękopiśmiennym oryginale przysporzył pewnych trudności, wskazano dwa możliwe rozpoznania, oba o sinojapońskim czytaniu sen: (1) 擅 implikujące ‘niepohamowaność, egoizm, despotyzm’ oraz (2) 氊 dawną formę znaku zapisywanego dzisiaj 氈 i oznaczającego filc i innego typu materiały, z których wytwarza się koce, pledy, narzuty i tym podobne (złożenie 毛亶 $m o \bar{s} s e n$ 'koc, pled, dywanik' jest używane dzisiaj powszechnie); niewykluczona też pomyłka autora listu, wynikła z fonetycznej tożsamości odczytu擅 i 氊 ～亶毛, a nawet zasugerowano możliwość „,problemu technicznego” (w trakcie pisania w tym momencie pisania zabrakło tuszu); inkryminowana forma rękopiśmienna faktycznie najbliższa zdawała się być znakowi 壇, odrzuconemu z powodu tak znaczenia ('ołtarz, podium, podest, scena, taras'), jak i odczytu (dan). 
是レ何人哉即于全 6 船客露国人其人卜ス

余八謹デ此々二其ノ厚情习謝ス

大日本帝国 広島縣 安佐郡 亀山村

勝木二○九番

横山實語

Transliteracja w systemie Hepburna

Yo Meiji sanjūkyūnen hachigatsu mikka hokubei gasshūkoku daihoku kisen

Dakotagō-nite Yokohama-yori [shatoru]-ni mikkō-o kuwada-

chi fukō shuppango futsuka jūgoji-ni senchō-ni hakken sare

hibi sennai-no jimu-ni jūji seri shikaru-ni kono fune

tōshin suru-ni shitagai kanki mashi kyō-wa hotondo Nihon-

ni oite tōki-to sarasara koto narazu kanki hanahada tsuyoshi

Yo motoyori mikkōsha nareba keitai butsugō-mo naku

shite jitsu-ni Ono kanki-ni kurushimi itari kono sai-ni nozo-

mite ichi-no jizenka arite yo-ni mōsen-o megumu

kore nanbito kana sunawachi zensen kyaku rokokujin sono hito-to su.

Yo-wa tsutsushinde koko-ni sono kōjō-o shasu.

Dai Nihon Teikoku Hiroshima-ken Asa-gun Kameyama-mura

Katsuki Nihyaku Kyū Ban

Yokoyama Jitsugo

Przekład

W dniu 23 sierpnia 39 roku Meiji [1906] zaplanowałem płynąć na gapę na parowcu Dakota należącym do US Great Northern Steamship na linii z Jokohamy do Seattle. Na nieszczęście dwa dni po odpłynięciu o godzinie 15 odkryty zostałem przez kapitana i odkomenderowany codziennie do pracy kancelaryjnej na statku. Jednakże w miarę posuwania się statku na wschód, robiło się coraz zimniej, a dzisiaj było prawie tak jak w japońską zimę. Było bardzo zimno. Jako pasażer na gapę nie miałem ze sobą podręcznych rzeczy i mogłem jeno cierpieć z zimna. Wtedy nadarzył się łaskawca, który był uprzejmy obdarować mnie pledem. Bardzo ciekaw kto nim był, dowiedziałem się, że był to jeden z pasażerów, Rosjanin. Wielce jestem wdzięczny za ten gest.

Jitsugo Yokoyama

zamieszkały w domu numer 209 w Katsuki, wieś Kameyama w gminie Asa Prefektury Hiroshima w Cesarstwie Wielkiej Japonii ${ }^{7}$.

6 소 stary wariant zapisu znaków 同 ‘ten sam, identyczny, podobny, równy’ oraz 全 ‘cały, pełny, kompletny, prawdziwy'.

7 Przekład angielskojęzyczny w Inoue \& Sawada 2010: 122-123; transkryptu z rękopisu i transliteracji na fonetyczny japoński sylabiczny zapis kana oraz na oparty na alfabecie łacńskim system Hepburna, a także (tu zmodyfikowanego) thumaczenia dokonała Anna Grądzka (2017: 38-42). 
Kontekst sytuacyjny (c.d.)

Nie ulega wątpliwości, że owym darczyńcą, „Rosjaninem”, był Bronisław Piłsudski, do którego ten list trafił i w jego bagażu dotarł aż do Polski, by przetrwać w zadbanych i dobrze strzeżonych pilsudskianach krakowskich Biblioteki Naukowej PAU i PAN po dzień dzisiejszy.

Według ustaleń Sawady wskazany w liście adres Yokoyamy to rejon masowej emigracji Japończyków przede wszystkim na Hawaje (z jego rodzinnej wsi w latach 1885-1907 miały wyjechać „za morza” aż 473 osoby), która mogła być dla gapowicza na Dakocie inspiracją. Yokoyama przeżył - choć w koszmarnych warunkach - i podróż, i pobyt w USA, a piątka z szóstki (czterech synów i dwie córki) jego potomstwa miała jeszcze na początku 2005 roku pozostawać wśród żywych w Stanach Zjednoczonych. Sawada dotarł do jego dalszego krewnego, który opowiedział, że Yokoyama znalazł się w USA nielegalnie, głodując i ukrywając się za dnia, a poruszając się po kraju nocami, dotarł do wuja w Los Angeles - miał wtedy „wyglądać jak mumia” (zob. Sawada \& Inoue 2010/2: 123).

List jest napisany w stylu typowym dla tamtych czasów, z użyciem opartego na klasycznej japońszczyźnie języka pisanego („literackiego”) określanego terminem bungo 文語. Oryginalny układ tekstu jest tradycyjny - od prawej do lewej, w pionowych kolumnach. Co bardzo ciekawe, forma zapisu przypomina oficjalne dokumenty, w których do zapisu nośników znaczeń gramatycznych zamiast pisarskich znaków sylabariusza hiragana używane były znaki sylabariusza kataka$n a$. Może to wskazywać na to, że Yokoyama miał relatywnie wysokie wykształcenie i mógł mieć styczność z oficjalnymi dokumentami. Potwierdzałby to też fragment samego listu: jego autor był przez kapitana odkomenderowany do pracy kancelaryjnej na statku. Pismo jest stosunkowo czytelne - nie udało się ani autorom, ani konsultantom odczytać tylko jednego znaku pisarskiego (por. przyp. 4). Może to też być użyte jako świadectwo tego, że szkolnictwo w Japonii jednak było powszechne i stało na wysokim poziomie, skoro chłopak ze wsi w biednym regionie potrafił tak wyrobioną ręką posługiwać się klasyczną japońszczyzną w piśmie.

Bronisław Piłsudski pozostał wiernym i wdzięcznym przyjacielem narodu japońskiego do końca swojego materialnie nędznego, a osobiście i rodzinnie nieszczęsnego życia.

Japonia pośmiertnie potraktowała go po cesarsku. W Shiraoi, na południu wyspy Hokkaido, stoi w skansenie ajnuskim jego pomnik, a na rekonstrukcję jego spuścizny naukowej i jej wprowadzenie w akademicki obieg wydano krocie. Ciemiężycielka Rosja potraktowała go - mimo „fatalnego nazwiska” - po carsku, w znaczeniu pozytywnym. Postawiono mu pierwszy gabrodiorytowy pomnik, ustanowiono Instytut Badania nad Dziedzictwem Naukowym - nie jego imienia, ale jego Dziedzictwa - który w ciągu swojego istnienia (1997-2016) opublikował 
20 tomów czasopisma poświęconego jego dokonaniom (IINBP), górze na południu Sachalinu ${ }^{8}$ nadano jego imię.

A jak potraktowała go Ojczyzna, którą kochał do szaleństwa i za którą on, wieczny tułacz, do szaleństwa tęsknił? Może chwilami i „chciano dobrze”, ale wyszło - ,jak zawsze”. Znaczek pocztowy i dwa srebrniki jednak mu się dostały, a ostatnio (maj 2018) nawet artystycznie i ideologicznie atrakcyjny pomnik rodzajowy pomysłu ajnuskiej artystki Maki Sekine stanął przed Muzeum Miejskim w Żorach. Bronisław w pozycji siedzącej (,po turecku”) wsłuchuje się w głos siedzącej (,po wschodniemu”, na złożonych piętach, z zamkniętymi oczami) naprzeciwko niego ajnuskiej narratorki nagrywany na stojący między nimi fonograf systemu Edisona. Nadal jednak „najważniejsze zasługi” etnografa, na których koncentrują się „polskie źródła naukowe”, to niestety „bycie bratem Marszałka” i ,popełnienie samobójstwa”.

\section{BIBLIOGRAFIA}

Bao Hexigetu 2013. Kawahara Misako-ni tsuite-no ichi kōsatsu // A Consideration of Kawahara Misako. „Kyūshū Kyōritsu Daigaku Kenkyū Kiyō” (Kita Kyūshū) 3/2, 53-63.

包賀喜格図2013。「河原操子についてのお一考察」。九州共立大学研究 紀要。第3 巻 第2 号。

Bao Hexigetu [\&] Bao Arong 2015. Kawahara Misako-no nihongo kyōiku katsudō-ni tsuite-no ichi kōsatsu [refleksje nad działalnością Misako Kawahary w zakresie nauczania języka japońskiego]. „Kyūshū Kyōritsu Daigaku Kenkyū Kiyō" (Kita Kyūshū) 5/2, 83-89.

包賀喜格図 [\&] 包阿栄2015。河原操子の日本語教育活動についてのお 一考察。九州共立大学研究紀要。第 5 巻 第 2 号。

Boyd, James 2005. A Forgotten 'Hero': Kawahara Misako and Japan's Informal Imperialism in Mongolia during the Meiji Period. „Intersections: «Gender and Sexuality in Asia and the Pacific Region»" 11.

(intersections.anu.edu.au/issue11/boyd.html Murdoch University).

CWBP 1 1998. The Collected Works of Bronisław Pitsudski. Volume 1. The Aborigines of Sakhalin edited by Alfred F. Majewicz. Ss. 816. Berlin \& New York: Mouton de Gruyter.

8 Szczyt o wysokość 419,2 m, znajdujący się w południowej części łańcucha Gór Schrencka, w okolicach osady Bykow w Rejonie Dolińskim.

9 Autorzy składają należne i bardzo zasłużone wyrazy wdzięczności i podziękowania panu profesorowi Kazuhiko Sawadzie z Uniwersytetu Saitama oraz pani dr Aleksandrze Jarosz z UMK i Uniwersytetu Ryukyu za pomoc w weryfikacji transkryptu oraz interpretacji tekstu. 
Grądzka, Anna 2017. Japonica wśród archiwaliów po Bronisławie Pitsudskim w Bibliotece Naukowej PAU i PAN w Krakowie. Listy Kimiko Torii i Jitsugo Yokoyamy, pokwitowanie opłaty celnej z Nagasaki. Toruń: Zakład Japonistyki Wydziału Filologicznego Uniwersytet Mikołaja Kopernika (Praca magisterska napisana pod kierunkiem prof. dra hab. Alfreda F. Majewicza).

Grodziska, Karolina 1998. Spuścizna rękopiśmienna Bronisława Piłsudskiego w zbiorach Biblioteki PAN w Krakowie i jej proweniencja. „Rocznik Biblioteki Polskiej Akademii Nauk w Krakowie" 43, 295-300.

IINBP „Известия Института наследия Бронислава Пилсудского” (wydawca Instytut Dziedzictwa Bronisława Piłsudskiego przy Sachalińskim Muzeum Regionalnym (Сахалинский областной краеведческий музей) w Jużno-Sachalinsku), tomy 1 (1998), 2 (1999), 3 (1999), 4 (2000), 5 (2001), 6 (2002), 7 (2004), 8 (2004), 9 (2005), 10 (2006), 11 (2007), 12 (2008), 13 (2009), 14 (2010), 15 (2011), 16 (2012), 17 (2013), 18 (2014), 19 (2015), 20 (2016).

Majewicz, Alfred F. 1999. Archiwalia po Bronistawie Pitsudskim w Bibliotece PAN w Krakowie $i$ ich wykorzystanie. „Rocznik Biblioteki Naukowej PAU i PAN w Krakowie" 44, 293-306.

Majewicz, Alfred F. 2007. Japonica w archiwaliach po Bronisławie Pitsudskim w Bibliotece PAU i PAN w Krakowie (1). Dwa listy Itoe Tachibany do Bronistawa Pitsudskiego. „Rocznik Biblioteki Naukowej PAU i PAN w Krakowie” 52, $399-420+3$ fotografie.

Majewicz, Alfred F. 2007a. Krakowski autograf Futabatei Shimei i jego kontekst. [tekst dla księgi jubileuszowej Profesora Mikołaja Melanowicza w druku, dostępny też jako IIEOS Preprint 43 (2007), Stęszew: International Institute of Ethnolinguistic and Oriental Studies, opublikowany] w: Romuald Huszcza i Bartosz T. Wojciechowski (red.) 2013. Inishie manabi aratashiki manabi Studia japonistyczne dedykowane Mikołajowi Melanowiczowi. Kraków: Wydawnictwo Uniwersytetu Jagiellońskiego. ss. 11-21.

Majewicz, Alfred F. 2008. Japonica w archiwaliach po Bronistawie Pitsudskim w Bibliotece PAU i PAN w Krakowie (2). Dwa dokumenty podróżne wydane Pitsudskiemu przez Konsulat Cesarstwa Japonii w Korsakowie. „Rocznik Biblioteki Naukowej PAU i PAN w Krakowie" 53, 251-258.

Majewicz, Alfred F. 2009. Japonica $w$ archiwaliach po Bronisławie Pitsudskim w Bibliotece Naukowej PAU i PAN w Krakowie 4. Listy Ajna Taronci w języku ajnuskim do Bronisława Pitsudskiego. ,Rocznik Biblioteki Naukowej PAU i PAN w Krakowie" 54, 381-405.

Majewicz, Alfred F. 2012. Japonica $w$ archiwaliach po Bronisławie Pitsudskim w Bibliotece Naukowej PAU i PAN w Krakowie (5). List Sentaro Kemuyamy do Susumi Uedy. „Rocznik Biblioteki Naukowej PAU i PAN w Krakowie” 57, 339-52. 
Majewicz, Alfred F. 2015. Japonica $w$ archiwaliach po Bronistawie Pitsudskim w Bibliotece Naukowej PAU i PAN w Krakowie (6). Corrigenda do Japonica 1 i [2]. „Rocznik Biblioteki Naukowej PAU i PAN w Krakowie” 60, 181-186. Majewicz, Alfred F. 2016. Japonica $w$ archiwaliach po Bronisławie Pitsudskim $w$ Bibliotece Naukowej PAU i PAN w Krakowie (7). Korespondencja panny K. do Bronisława Pitsudskiego. „Rocznik Biblioteki Naukowej PAU i PAN w Krakowie" 61, 161-181.

Sawada Kazuhiko 2007. Bakumatsu, Meiji, Taishōki-no Nihon-to Roshia-no bunka kōryū-ni kansuru jisshōteki kenkyū - Исследования истории русско-японских отношений и новые материальк к ним (середина XIX-середина $X X$ веков) [studia nad dziejami stosunków rosyjsko-japońskich w okresach Bakumatsu, Meiji i Taishō i nowo odkryte materiały z nimi związane - połowa XIX i pierwsze dekady XX wieku]; zob. szczególnie "The Japanese Calendarium: Bronisław Piłsudski in Japan" po angielsku (s. 111-163), rosyjsku (s. 65-110) i po japońsku (s. 25-64)]. Saitama: Saitama University.

澤田和彦2007。幕末. 明治. 大正期の日本とロシアの文化交流に関す る実証的研究。さいたま市：埼玉大学教養学部。

Sawada Kazuhiko \& Kōichi Inoue (eds.) 2010. A Critical Biography of Bronistaw Pitsudski. Vols. 1-2. Saitama: Saitama University Faculty of Liberal Arts.

ANNA GRĄDZKA

ALFRED F. MAJEWICZ

\section{JAPONICA IN THE ARCHIVES LEFT AFTER BRONISŁAW PIŁSUDSKI \\ IN THE CRACOW PAU-PAN ACADEMIC LIBRARY \\ 8. KIMIKO TORII'S LETTER TO BRONISŁAW}

AND MITSUGO YOKOYAMA'S LETTER WRITTEN ON BOARD S/S DAKOTA

Keywords: Piłsudski Bronisław, Torii Ryzo, Torii Kimiko, Kawahara Misako, Piłsudski's archives in Kraków, Japanese emigration to America, Japan and Mongolia, S/S Dakota

Summary

The present material constitutes the eighth installment of the presentation of Japanese documents preserved with Bronisław Piłsudski's archives in the Academic Library of the Polish Academy of Sciences and Lettres (PAU) and Polish Academy of Sciences (PAN) in Cracow and includes two letters in facsimile, transliteration, and interpretation in Polish. The first of them has been written in Japanese but in Roman characters (römaji) with few insertions in French. Its author, Kimiko Torii was the wife of the renowned Japanese ethnographer and anthropologist Ryūzō Torii who traveled extensively and conducted fieldwork in many places studying numerous cultures, the Ainu, especially the Kuril Ainu, included. Bronisław was personally acquainted with the couple - Ryuzo translated (from German) and published Bronisław's work “The Aborigines of Sakhalin” (English 
translation in CWBP 1, 222-235), and Bronisław went to the railway station in Tokyo to see Kimiko off on her way to Mongolia to join her husband there - both conducted research in that country but the primary reason for Kimiko was to go on invitation from a local prince to Harqin (today in Inner Mongolia in China) to replace another Japanese lady in teaching in a school for Mongolian, primarily the prince's, children - Misako Kawahara. Both ladies left several memoir publications each on their stay and experience accumulated in Mongolia, Kimiko coauthored also some works of academic importance with Ryuzo. Basic data on all the three persons and details concerning some of the publications mentioned have been provided. The letter is personal and, explaining circumstances, constitutes a plea for excuse for failed encounter on a snowy winter evening (beginning of February 1906) at the Toriis'.

The other letter has been written by a person from Hiroshima Prefecture named Mitsugo Yokoyama who happened to board S/S Dakota on the way from Japan to the USA as a stowaway. Freezing while in hiding, he was offered a warm blanket from "a Russian" which helped him to survive. The letter does not mention the donor's name and was probably written as sort of a statement for the captain but also as a letter of the deepest gratitude toward the "Russian". Finding the moving letter in Cracow allows a supposition that it had been handed over to Piłsudski by its receiver. Kazuhiko Sawada succeeded in tracing the lot of the then lucky beneficiary who survived the journey and his and his family hard times in America (he had six children, five of them allegedly still alive in 2005).

Some remarks on the language of the letters and on Bronisław's nature have also been made. It is the first among all so-far published installments in the Japonica series emerging in co-authorship: Ms. Anna Grądzka prepared the tentative versions of the decipherment of the manuscript originals, and their transliterations and translations within the framework of her MA thesis in Japanese studies at Nicoalus Copernicus University in Torun.

АННА ГРОНДЗКА (ANNA GRĄDZKA)

АЛЬФРЕД Ф. МАЕВИЧ (ALFRED F. MAJEWICZ)

\author{
ЯПОНСКИЙ СЛЕД В АРХИВАХ, \\ ОСТАВШИХСЯ ПОСЛЕ БРОНИСЛАВА ПИЛСУДСКОГО \\ В НАУЧНОЙ БИБЛИОТЕКЕ ПОЛЬСКОЙ АКАДЕМИИ ЗНАНИЙ \\ И ПОЛЬСКОЙ АКАДЕМИИ НАУК \\ 8. ПИСЬМО КИМИКО ТОРИИ БРОНИСЛАВУ ПИЛСУДСКОМУ \\ И ПИСЬМО МИЦУГО ЁКОЯМА, НАПИСАННОЕ НА БОРТУ ПАРОХОДА ДАКОТА
}

Ключевые слова: Пилсудский Б.О. (Бронислав), Тории Рюдзо, Тории Кимико, Кавахара Мисако, архивные материалы Б.О. Пилсудского в фондах архивов Кракова, японская эмиграция в Америку, Япония и Монголия, Дакота пароход

Резюме

Настоящий материал представляет собой восьмую часть презентации японских документов, хранящихся в архивах Бронислава Пилсудского в Научной библиотеке Польской академии знаний (PAU) и Польской академии наук (PAN) в Кракове, 
и включает два факсимильных воспроизведения писем, их транслитерацию и перевод на польский язык. Первое из них было написано на японском языке буквами латинского алфавита (rōmaji) с несколькими вставками на французском языке. Кимико Тории была супругой знаменитого японского этнографа и антрополога Рюдзо Тории, много путешествовавшего и изучавшего в полевых условиях различные культуры, включая культуру айнов, в частности, проживающих на Курильских островах. Бронислав был лично знаком с этой парой - Рюдзо перевел (с немецкого) и опубликовал работу Пилсудского под названием «Аборигены Сахалина» (перевод на английский язык в CWBP 1, 222-235), а Бронислав отправился на железнодорожный вокзал в Токио, чтобы проводить Кимико в Монголию, где она должна была присоединиться к своему супругу - оба они занимались исследованиями в этой стране, однако основной причиной поездки Кимико было приглашение от местного князя в Харачин (сегодня находится в районе Внутренняя Монголия, Китай) в качестве замены для японской учительницы, занимавшейся с местными детьми (в основном, с детьми князя) - Мисако Кавахара. Обе женщины оставили после себя мемуары о своей жизни в Монголии, а Кимико в соавторстве с Рюдзо также опубликовала несколько научных работ. В материале также представлены основные сведения обо всех трех персонах и подробная информация о некоторых из упомянутых публикаций. Письмо является личным, и его автор, объясняя обстоятельства, просит прощения за неудавшуюся встречу снежным зимним вечером (в начале февраля 1906 г.) в доме семьи Тории.

Другое письмо было написано человеком из префектуры Хиросима по имени Мицуго Ёкояма, который проник на борт парохода «Дакота», идущего из Японии в США, без билета. Скрываясь от посторонних глаз, он сильно замерз, а пережить холод ему помог один «русский», предложивший ему теплое одеяло. В письме не упоминается имя благодетеля, и написано оно было, скорее всего, как объяснительная на имя капитана, но в то же время содержит очень много теплых слов в адрес «русского». Тот факт, что это письмо было найдено в Кракове, дает повод предположить, что оно было передано Пилсудскому его получателем. Кадзухико Саваде удалось отследить судьбу того безбилетного пассажира, который пережил не только путешествие, но и трудности, с которыми столкнулась его семья в Америке (у него было шесть детей, и пятеро из них в 2005 году еще были живы).

Также приводится несколько комментариев об используемой в письмах лексике и о характере Бронислава. Это первая из опубликованных на данный момент частей серии Japonica, созданных в соавторстве: черновые версии расшифровок рукописных оригиналов, а также их транслитерации и переводы были подготовлены г-жой Анной Грондзкой в рамках магистерской диссертации по японоведению в Университете Николая Коперника в Торуни. 